\title{
PENINGKATAN SIKAP ILMIAH SISWA MELALUI PEMBELAJARAN BERBASIS PRAKTIKUM VIRTUAL INVERTEBRATA
}

\author{
Peny Husna Handayani ${ }^{{ }^{1}}$, Fransisca Sudargo Tapilouw ${ }^{2}$, Ana Ratna Wulan ${ }^{3}$ \\ ${ }^{1}$ FIP, UNIMED, JI. Willem Iskandar Ps V, Medan, Sumatera Utara, Indonesia \\ ${ }^{2,3}$ Pendidikan Biologi, Sekolah Pascasarjana, UPI, Jl. Setiabudi No.229, Bandung, Jawa Barat, Indonesia \\ *Email: peny_husna@unimed.ac.id
}

\begin{abstract}
ABSTRAK
Penelitian ini bertujuan untuk menganalisis peningkatan sikap ilmiah siswa melalui pembelajaran berbasis praktikum virtual. Metode penelitian yang digunakan adalah weak experimental design, dengan dua kelas sampel (X-7 dan X-8) yang memiliki kedudukan sejajar sebagai kelas perlakuan. Instrumen yang digunakan untuk pengambilan data adalah skala sikap ilmiah berbentuk skala Likert. Hasil penelitian menunjukkan bahwa sikap ilmiah mengalami peningkatan yang signifikan setelah pembelajaran berbasis praktikum virtual (nilai sig2 tailed $<\alpha(0,025)$ ). Peningkatan sikap ilmiah tergolong rendah $(N$-Gain $X-7=0,10 ; X-8=0,16)$. Program praktikum virtual ini bukan sebagai pengganti laboratorium nyata, tetapi sebagai pelengkap bagi pembelajaran dengan materi yang sulit dilakukan di laboratorium nyata, seperti praktikum invertebrata.
\end{abstract}

Kata kunci: invertebrate, praktikum virtual, sikap ilmiah.

\section{ABSTRACT}

This study aims to analyze the students' scientific attitude improvement through virtual lab on invertebrates. The method that used was weak experimental design, with two classes of samples (X-7 and X-8) which has a parallel position as class treatment. The instrument that used for data collection was the scientific attitudes scale form of Likert scale. The results showed that the scientific attitudes improved significantly after virtual lab-based learning on invertebrates (sig-2tailed value $<\alpha(0.025)$ ). Increased scientific attitude is low ( $\mathrm{N}$ Gain X-7 $=0.10,=0.16 \mathrm{X}-8$ ). Virtual lab program is not a substitute for a real lab, but as a complement for learning of the material that is hard to do in a real laboratory, such as the practicum invertebrates.

Keywords: invertebrates, virtual lab, scientific attitudes

\section{PENDAHULUAN}

Pengembangan kemampuan berpikir dan penguasaan konsep harus seimbang dengan sikap yang muncul dari seseorang sebagai hasil proses belajarnya. Aspek sikap yang terkait dengan IPA, termasuk biologi, menitikberatkan kepada sikap ilmiah. Kompetensi sains harus diarahkan salah satunya untuk menjamin pertumbuhan dan kemampuan bekerja serta sikap ilmiah. Sikap ilmiah, seperti objektif, terbuka, ulet, dan dapat bekerja sama dengan orang lain, menjadi karakter bangsa yang diharapkan muncul dari pembelajaran biologi. Penelitian yang telah dilakukan tentang sikap ilmiah oleh Iswari (2008) menyatakan bahwa sikap ilmiah adalah salah satu faktor yang perlu dipertimbangkan dalam proses pembelajaran untuk meningkatkan prestasi belajar.

Kegiatan pembelajaran biologi sebaiknya dikemas sedemikian rupa sehingga mampu memfasilitasi siswa untuk mengembangkan tidak hanya penguasaan konsep dan kemampuan berpikir, tetapi juga sikap ilmiahnya. Pemberian pengalaman langsung, seperti kegiatan praktikum, dapat menjadi salah satu metode pembelajaran yang dapat digunakan untuk mencapai tujuan pembelajaran biologi tersebut. Woolnough \& Allsop (dalam Rustaman et al., 2003: 160) mengemukakan bahwa kegiatan praktikum dapat membangkitkan motivasi belajar siswa, mengembangkan keterampilan dasar melakukan eksperimen, menjadi wahana belajar pendekatan ilmiah, dan tentunya menunjang materi pelajaran. Berdasarkan hasil observasi pada tahap persiapan penelitian, dapat diketahui bahwa kegiatan praktikum, khususnya praktikum biologi di sekolah sering menemui hambatan seperti permasalahan waktu atau keterbatasan alat dan bahan. Adakalanya untuk melakukan praktikum pengamatan objek biologi, kita harus mengamatinya melalui media awetan basah atau 
pun kering, sedangkan ketersediaan media awetan tersebut di laboratorium sekolah tidak selengkap di universitas. Beberapa media awetan yang ada pun kondisinya tidak terlalu baik, misalnya tubuh hewan yang diawetkan sudah tidak lengkap lagi dan warna tubuh hewan tersebut sudah memudar. Kondisi demikian menyebabkan minat siswa untuk melakukan praktikum menjadi berkurang. Tidak jarang akhirnya guru mengganti kegiatan praktikum dengan kegiatan ceramah di dalam kelas. Tentu saja ini menjadikan pembelajaran biologi yang seharusnya menyenangkan dan memberi kesempatan yang besar bagi siswa untuk mengeksplor rasa ingin tahunya, menjadi suatu mata pelajaran yang membosankan dengan materi bacaan yang cukup banyak.

Kegiatan praktikum virtual sebagai produk dari kemajuan teknologi dapat menjadi solusi alternatif untuk mengatasi hambatan-hambatan tersebut. Permasalahan yang berkaitan dengan waktu dalam melakukan kegiatan praktikum di laboratorium, dapat diatasi dengan adanya praktikum virtual. Pembelajaran berbasis praktikum virtual dikatakan oleh Carnevale (2003: 2) dapat memberikan keleluasaan (flexibility) terhadap waktu dan tempat dalam melakukannya. Hambatan lain seperti kesulitan mendapatkan bahan praktikum atau beresiko karena bahan tersebut berada di lingkungan yang berbahaya dapat diatasi dengan kegiatan praktikum virtual. Praktikum virtual memberikan pengalaman bereksperimen yang aman dan menyenangkan bagi siswa (Carnevale, 2003: 1). Pemanfaatan teknologi virtual dapat membawa berbagai jenis lingkungan atau ekosistem alami yang eksotis dengan komponen-komponennya ke dalam kelas (Hill \& Nelson, 2011: 3) sehingga diharapkan dapat membantu mengatasi keterbatasan alat dan bahan dalam melakukan kegiatan praktikum.

Materi invertebrata merupakan salah satu materi biologi di kelas $X$ yang berpotensi untuk melatihkan sikap ilmiah siswa. Pembelajaran pada materi invertebrata ini menuntut siswa untuk melakukan pengamatan, identifikasi, sampai mampu mendeskripsikan ciri-ciri Filum pada dunia hewan invertebrata. Materi ini menuntut adanya kegiatan praktikum, namun, ketersediaan bahan awetan di sekolah sering sangat tidak memadai.
Oleh karena itu, pembelajaran berbasis praktikum virtual menjadi alternatif solusi yang mungkin untuk dilakukan. Diharapkan dengan pembelajaran berbasis praktikum virtual pada materi invertebrata, siswa seolah-olah dapat melakukan pengamatan pada habitat aslinya, penangkapan, pembedahan, sampai pendeskripsian ciri-ciri hewan invertebrata.

\section{METODE PENELITIAN}

Metode penelitian yang digunakan adalah weak experimental design. Tidak ada kelas kontrol pada weak experiment. Penelitian ini dimaksudkan untuk menguji hipotesis tentang hubungan sebab akibat, mempengaruhi dan atau memanipulasi variabel bebas kemudian melihat pengaruh dari perlakuan tersebut (Fraenkel dan Wallen, 2007: 257-258). Pada penelitian yang dilakukan ini, tidak dimungkinkan adanya kelas yang setara pembelajarannya dengan pembelajaran berbasis praktikum virtual, terutama berkaitan dengan ketersediaan spesimen untuk diamati. Oleh karena itu, tidak ada kelas kontrol dan metode penelitian yang sesuai adalah weak experiment

Penelitian ini dilaksanakan di SMA Negeri 8 Bandung, yang berlokasi di Jalan Solontongan nomor 3, Buah Batu, Bandung. Populasi dalam kegiatan penelitian ini adalah siswa-siswi kelas $X$ di SMA Negeri 8 Bandung sebanyak 11 kelas. Sampel yang digunakan untuk penelitian adalah siswa-siswi kelas X-7 dan X-8 yang masing-masing kelas berjumlah 38 orang siswa. Pemilihan sampel penelitian ini dilakukan dengan menggunakan teknik cluster random sampling dari populasi yang ada (menetapkan kelas sampel secara acak tanpa mengacak siswa di tiap kelasnya). Kedua kelas tersebut diberi kegiatan belajar dan tes yang sama, sehingga tidak ada kelas kontrol. Kedudukan kedua kelas disejajarkan. Hal ini dilakukan dengan tujuan agar peneliti dapat memperoleh data yang lebih mendalam dan saling melengkapi, sehingga pada akhirnya dapat menyusun kesimpulan yang baik meskipun metode penelitian yang dilakukan adalah weak experiment.

Pengumpulan data dalam penelitian ini dilakukan dengan menggunakan instrumen skala sikap dan angket tanggapan siswa terhadap pembelajaran. Skala sikap digunakan untuk 
mengetahui sikap ilmiah siswa sebelum dan sesudah pembelajaran berbasis praktikum virtual pada materi invertebrata. Skala sikap yang digunakan pada penelitian ini menggunakan skala Likert yang meliputi sejumlah 20 pernyataan sikap ilmiah dengan mengacu pada kurikulum mata pelajaran biologi SMA yang disusun oleh pusat kurikulum (PUSKUR)-Balitbang Diknas dikombinasikan dengan sikap ilmiah menurut Carin (1997). Skala Likert yang digunakan memiliki empat pilihan jawaban, yaitu Sangat Tidak Setuju (STS), Tidak Setuju (TS), Setuju (S), dan Sangat Setuju (SS) dengan skala 1-4.

\section{HASIL PENELITIAN}

Sikap Ilmiah yang diukur dalam penelitian ini meliputi rasa ingin tahu, teliti, objektif, mau menerima perbedaan dan bekerja sama. Sikap ilmiah siswa pada pembelajaran berbasis praktikum virtual dijaring dengan menggunakan 20 pernyataan skala Likert sikap ilmiah yang memiliki empat pilihan jawaban, yaitu Sangat Tidak Setuju (STS), Tidak Setuju (TS), Setuju (S), dan Sangat Setuju (SS) dengan skala 1-4.

Peningkatan sikap ilmiah siswa pada masing-masing kelas sampel, yaitu kelas X-7 dan X8, diperoleh dari selisih skor skala sikap akhir dan awal selama pembelajaran berbasis praktikum virtual pada materi invertebrata. Data selengkapnya dapat dilihat pada Tabel 1.

Tabel 1. Rekapitulasi Perhitungan Skor Sikap IImiah

\begin{tabular}{ccccc}
\hline Kelas & $\begin{array}{c}\text { Rata-Rata } \\
\text { Skala Sikap Awal }\end{array}$ & $\begin{array}{c}\text { Rata-Rata } \\
\text { Skala Sikap Akhir }\end{array}$ & N-gain & Kategori \\
\hline X-7 & 2,90 & 3,01 & 0,10 & rendah \\
X-8 & 3,03 & 3,18 & 0,16 & rendah \\
\hline
\end{tabular}

Berdasarkan Tabel 1 dapat diketahui bahwa terjadi peningkatan sikap ilmiah siswa pada masing-masing kelas sampel. Masing-masing kelas sampel menunjukkan bahwa skala sikap ilmiah akhir lebih baik dari skala sikap ilmiah awal. Berdasarkan kategorisasi menurut Hakel (1998, dalam Meltzer, 2002), maka masing-masing kelas sampel tersebut mengalami peningkatan sikap ilmiah siswa dengan kategori rendah. Uji hipotesis peningkatan sikap ilmiah kelas X-7 dan X-8 dapat dilihat pada Tabel 2 berikut:

Tabel 2 Hasil Uji Hipotesis Sikap IImiah Siswa Kelas X-7 dan X-8

\begin{tabular}{cccc}
\hline Data & $\begin{array}{c}\text { Asymp.Sig. (2- } \\
\text { tailed })\end{array}$ & $\begin{array}{c}\text { Penerimaan } \mathrm{H}_{\mathbf{0}} \\
(\boldsymbol{\alpha}=\mathbf{0 , 0 2 5 )}\end{array}$ & Kesimpulan \\
\hline Skala Sikap Ilmiah Awal \& Akhir X-7 & 0,004 & Tolak $\mathrm{H}_{0}$ & Ada peningkatan signifikan \\
Skala Sikap IImiah Awal \& Akhir X-8 & 0,000 & Tolak $\mathrm{H}_{0}$ & Ada peningkatan signifikan \\
\hline
\end{tabular}

Tabel 2 di atas menunjukkan bahwa nilai signifikansi (Sig) sikap ilmiah siswa kelas X-7 dan X8 lebih kecil $(<)$ dari $\alpha(0,025)$, sehingga Ho ditolak dan $\mathrm{H}_{1}$ diterima, artinya bahwa terdapat peningkatan sikap ilmiah yang signifikan pada siswa kelas X-7 dan siswa kelas X-8 setelah pembelajaran berbasis praktikum virtual pada materi invertebrata.
Sikap ilmiah yang diukur dalam penelitian ini difokuskan pada lima aspek meliputi rasa ingin tahu, teliti, objektif, mau menerima perbedaan dan bekerja sama. Perolehan rerata skor skala sikap awal dan akhir pada setiap aspek sikap ilmiah siswa kelas X-7 dapat dilihat pada Tabel 3 berikut. 
Tabel 3 Rerata Skor Skala Sikap Awal dan Akhir Per Aspek Sikap Ilmiah Siswa Kelas X-7

\begin{tabular}{|c|c|c|c|c|}
\hline \multirow[t]{2}{*}{ Aspek Sikap Ilmiah } & \multicolumn{2}{|c|}{ Rerata Skor } & \multirow[t]{2}{*}{ N-Gain } & \multirow[t]{2}{*}{ Keterangan } \\
\hline & Skala Sikap Awal & Skala Sikap Akhir & & \\
\hline Rasa ingin tahu & 3,24 & 3,30 & 0,08 & Rendah \\
\hline Teliti & 3,09 & 3,03 & - & Tdk ada peningkatan \\
\hline Objektif & 2,85 & 2,75 & - & Tdk ada peningkatan \\
\hline $\begin{array}{l}\text { Mau menerima perbedaan } \\
\text { (menghormati perbedaan) }\end{array}$ & 3,09 & 3,10 & 0,01 & Rendah \\
\hline Bekerja sama & 2,97 & 3,06 & 0,09 & Rendah \\
\hline
\end{tabular}

Tabel 3 menunjukkan bahwa tidak seluruh aspek sikap ilmiah mengalami peningkatan setelah pembelajaran invertebrata berbasis praktikum virtual di kelas X-7. Sebanyak dua aspek sikap ilmiah, yaitu aspek teliti dan objektif menunjukkan rerata skor skala sikap akhir lebih rendah daripada skor skala sikap awal, sehingga dapat dikatakan tidak terjadi peningkatan setelah pembelajaran. Sedangkan, tiga aspek lainnya, yaitu aspek rasa ingin tahu, mau menerima perbedaan (menghormati perbedaan), dan bekerja sama, menunjukkan rerata skor skala sikap akhir lebih tinggi dari pada skor skala sikap awal. Berdasarkan nilai $N$-gainnya, maka peningkatan yang terjadi pada tiga aspek tersebut tergolong dalam kategori rendah. Selanjutnya, perolehan rerata skor skala sikap awal dan akhir pada setiap aspek sikap ilmiah siswa kelas X-8 dapat dilihat pada Tabel 4 berikut.

Tabel 4. Rerata Skor Skala Sikap Awal dan Akhir Per Aspek Sikap Ilmiah Siswa Kelas X-8

\begin{tabular}{|c|c|c|c|c|}
\hline \multirow[t]{2}{*}{ Aspek Sikap Ilmiah } & \multicolumn{2}{|c|}{ Rerata Skor } & \multirow[t]{2}{*}{ N-Gain } & \multirow[t]{2}{*}{ Ket. } \\
\hline & Skala Sikap Awal & Skala Sikap Akhir & & \\
\hline Rasa ingin tahu & 3,48 & 3,30 & - & Tdk ada peningkatan \\
\hline Teliti & 3,12 & 3,23 & 0,13 & Rendah \\
\hline Objektif & 2,90 & 2,96 & 0,05 & Rendah \\
\hline $\begin{array}{l}\text { Mau menerima perbedaan } \\
\text { (menghormati perbedaan) }\end{array}$ & 3,22 & 3,25 & 0,04 & Rendah \\
\hline Bekerja sama & 3,32 & 3,21 & - & Tdk ada peningKatan \\
\hline
\end{tabular}

Seperti halnya pada kelas X-7, peningkatan sikap ilmiah siswa di kelas X-8 pun tidak terjadi di setiap aspek sikap ilmiah yang telah ditentukan. Tabel 4.13 menunjukkan bahwa rerata skor skala sikap ilmiah akhir aspek rasa ingin tahu dan bekerja sama lebih rendah daripada rerata skor skala sikap ilmiah awal, sehingga dapat dikatakan tidak terjadi peningkatan setelah pembelajaran pada kedua aspek tersebut. Sedangkan, tiga aspek lainnya, yaitu aspek teliti, objektif, dan mau menerima perbedaan (menghormati perbedaan) menunjukkan rerata skor skala sikap ilmiah akhir lebih tinggi dari pada rerata skor skala sikap ilmiah awal. Berdasarkan nilai N-gainnya, maka peningkatan yang terjadi pada tiga aspek tersebut tergolong dalam kategori rendah.

\section{PEMBAHASAN}

Tabel 1 menunjukkan bahwa masingmasing kelas sampel mengalami peningkatan sikap ilmiah setelah pembelajaran berbasis praktikum virtual pada materi invertebrata. Peningkatan sikap ilmiah siswa pada masing-masing kelas sampel tersebut termasuk pada kategori rendah (Tabel 1).

Peningkatan sikap ilmiah yang rendah ini berkaitan dengan terbatasnya waktu pelaksanaan pembelajaran berbasis praktikum virtual yang dilakukan pada materi invertebrata ini. Penelitian ini dilakukan dalam tiga kali pertemuan. Setiap pertemuan berlangsung selama dua kali jam pelajaran ( 2 x 90 menit). Dengan demikian, dapat dikatakan bahwa proses peningkatan sikap ilmiah siswa melalui pembelajaran berbasis praktikum virtual berlangsung dalam waktu yang terbatas. 
Sedangkan, proses pembentukan sikap, termasuk sikap ilmiah, kompleks dan melibatkan interaksi antar faktor pembentuknya, sehingga membutuhkan waktu yang lama (Azwar, 2009: 3036).

Berdasarkan hasil analisis uji hipotesis pada masing-masing kelas sampel (Tabel 2) dapat diketahui bahwa peningkatan sikap ilmiah tersebut juga signifikan. Hasil angket menunjukkan bahwa pembelajaran berbasis praktikum virtual sangat baik (91\%) untuk membantu siswa dalam mengembangkan sikap ilmiahnya. Proses pembelajaran berbasis praktikum virtual yang dilakukan memberikan kesempatan kepada siswa untuk mengembangkan sikap ilmiah mereka, seperti rasa ingin tahu, ketelitian, objektifitas, bekerja sama, dan mau menerima perbedaan.

Pembelajaran berbasis praktikum virtual pada materi invertebrata memberikan pengaruh yang sama pada sikap ilmiah siswa di kelas $X-7$ dan X-8. Siswa-siswa di kelas X-7 dan X-8 mendapatkan kegiatan pembelajaran yang sama pada materi invertebrata, yaitu pembelajaran berbasis praktikum virtual. Siswa terlibat langsung dalam kegiatan pembelajaran berbasis praktikum virtual yang diarahkan agar mereka dapat mengembangkan rasa ingin tahu, ketelitian, objektifitas, bekerja sama, dan mau menerima perbedaan. Keterlibatan siswa secara langsung dalam kegiatan pembelajaran berperan penting dalam pengembangan sikap ilmiah siswa. Knuth, Jones, dan Baxendale (1991, dalam Keller dan Keller, 2005: 3) menguatkan bahwa kegiatan praktikum dan proses belajar yang melibatkan keaktifan siswa secara langsung dapat melatih siswa untuk bersikap dan bertindak sebagai seorang ilmuwan yang baik.

Terdapat lima aspek sikap ilmiah yang menjadi fokus dalam penelitian ini. Peningkatan sikap ilmiah pada setiap aspeknya dianalisis pada masing-masing kelas sampel. Siswa kelas X-7 mengalami peningkatan dengan kategori rendah pada tiga aspek sikap ilmiah, yaitu "rasa inging tahu" (N-Gain 0,08), "menghormati perbedaan" ( $N$-Gain 0,005), dan "bekerja sama" (N-Gain 0,09). Sedangkan dua aspek lainnya, yaitu "teliti" dan "objektif" menunjukkan tidak ada peningkatan.
Peningkatan setiap aspek sikap ilmiah pada siswa kelas $X-8$ tidak jauh berbeda dengan yang terjadi pada kelas X-7. Sebanyak tiga aspek sikap ilmiah mengalami peningkatan rendah, dan dua aspek lainnya tidak meningkat. Ketiga aspek sikap ilmiah mengalami peningkatan rendah, yaitu "teliti" (N-Gain 0,13), "objektif" (N-Gain 0,05), dan "menghormati perbedaan" ( $N$-Gain 0,04$)$. Ratarata peningkatan setiap aspek sikap ilmiah di kelas X-7 dan X-8, tergolong pada kategori rendah.

Aspek sikap ilmiah yang pertama, yaitu "rasa ingin tahu", dan aspek sikap ilmiah yang terakhir, yaitu "bekerja sama", meningkat dengan kategori rendah di kelas X-7 (Tabel 3), dan di kelas X-8 tidak terjadi peningkatan (Tabel 4). Skor skala sikap ilmiah siswa akhir lebih rendah daripada skor skala sikap ilmiah siswa awal. Hasil ini tidak sesuai dengan tanggapan siswa dalam angket yang menyatakan bahwa pembelajaran berbasis praktikum virtual sangat baik (98\%) dalam memfasilitasi rasa ingin tahu siswa dan baik (82\%) dalam membantu hubungan kerja sama siswa antar kelompok pada masing-masing kelas sampel. Ketidaksesuaian ini mungkin disebabkan oleh variabel extranous (variabel luar) lainnya yang tidak terkontrol oleh peneliti. Variabel extranous tersebut seperti kondisi siswa sudah lelah dan sudah bosan dengan pengisian skala sikap ilmiah yang diberikan. Tapilouw (2011: 6) mengemukakan bahwa variabel extranous yang tidak berhasil dikendalikan atau diminimalkan pengaruhnya akan berpengaruh terhadap variabel terikatnya. Dalam hal ini, variabel terikat tersebut adalah aspek sikap ilmiah "rasa ingin tahu" dan "bekerja sama".

Aspek sikap ilmiah selanjutnya adalah "teliti" dan "objektif". Kedua aspek sikap ilmiah ini tidak mengalami peningkatan di kelas X-7 (Tabel 3). Namun, mengalami peningkatan rendah di kelas $X$ 8 (Tabel 4). Berdasarkan hasil pengamatan peneliti, selama proses pembelajaran berbasis praktikum virtual, siswa tidak khawatir salah dalam melakukan kerja ilmiah, seperti membedah, menyayat, dan mengamati, karena dalam program praktikum virtual tersebut, siswa bisa mengulangi kegiatannya jika mereka melakukan kesalahan. Hal ini, menjadikan ketelitian siswa kelas X-7 tidak mengalami peningkatan dan siswa kelas $X-8$ hanya mengalami peningkatan yang rendah. Temuan ini 
sesuai dengan yang dinyatakan oleh McMaster (2011) bahwa kemudahan siswa untuk mengubah setting atau menu pada simulasi komputer seperti pada program praktikum virtual membuat siswa tidak belajar tentang ketelitian.

Aspek sikap ilmiah "mau menerima perbedaan" mengalami peningkatan rendah pada masing-masing kelas sampel (Tabel 3 dan 4). Berdasarkan hasil pengamatan peneliti, dapat diketahui bahwa data atau informasi yang didapatkan siswa dalam pembelajaran invertebrata berbasis praktikum virtual, tidak menimbulkan adanya perbedaan sudut pandang yang berarti di antara siswa pada masing-masing kelas sampel. Siswa tidak tertantang untuk menerima dan menghormati perbedaan sudut pandang sampai menemukan kecocokan data seperti yang dikatakan oleh Carin (1997: 14) sebagai penjelasan sub indikator "mau menerima perbedaan".

Secara umum, pembelajaran berbasis praktikum virtual dapat menjadi proses pembelajaran alternatif yang menuntut keaktifan siswa dalam belajar, sehingga membantu pengembangan sikap ilmiah siswa, yang pada dasarnya bersifat dinamis. Sebagaimana yang dikemukakan oleh Schafresman (1991) bahwa pengembangan sikap ilmiah erat kaitannya dengan keterlibatan siswa secara aktif selama proses pembelajaran. Fitriani (2011: 80) pun menyatakan bahwa peningkatan dan penurunan skala sikap ilmiah siswa setiap aspeknya menunjukkan bahwa sikap seseorang bersifat dinamis, dapat mengalami perubahan karena adanya proses pembelajaran.

\section{KESIMPULAN}

Berdasarkan hasil penelitian yang telah dilakukan menunjukkan bahwa pembelajaran berbasis praktikum virtual dapat meningkatkan sikap ilmiah siswa pada materi invertebrata. Hasil uji hipotesis menunjukkan bahwa terdapat peningkatan yang signifikan untuk sikap ilmiah siswa pada masing-masing kelas sampel melalui pembelajaran berbasis praktikum virtual. Sikap ilmiah siswa meningkat secara signifikan, namun tergolong kategori rendah. Proses pembentukan sikap membutuhkan waktu yang lama, sedangkan pembelajaran berbasis praktikum virtual dilakukan dalam waktu yang terbatas, sehingga peningkatan sikap ilmiah siswa hanya dapat terjadi pada kategori rendah.

Berdasarkan hasil temuan dari penelitian yang dilakukan, beberapa saran untuk melengkapi penelitian selanjutnya, diantaranya adalah program virtual sebaiknya di-setting agar dapat compatible di setiap setting komputer atau laptop bahkan tab sekali pun. Pengaturan waktu saat pelaksanaan pembelajaran berbasis praktikum harus diperhatikan oleh guru dan dipertegas kepada siswa, sehingga siswa tidak terlalu asyik saat melaksanakan pembelajaran berbasis praktikum virtual yang berakibat tidak selesainya target praktikum. Guru bisa memberitahukan siswa bahwa mereka dapat mengulang dan "mengulik" kembali program praktikum virtual tersebut di luar jam pelajaran atau di rumah untuk memenuhi rasa ingin tahu mereka. Terdapat kemampuankemampuan atau karakteristik lain yang berbeda yang masih perlu ditelusuri pada penelitian sejenis.

\section{UCAPAN TERIMAKASIH}

Ucapan terimakasih penulis ucapkan kepada Bapak Kepala Sekolah SMA Negeri 8 Bandung, Drs. Ujang, kepada Ibu Dra. Tintin Suhartini sebagai guru biologi di kelas X SMAN 8 Bandung, yang telah memberikan izin dan membantu selama proses pengumpulan data.

\section{DAFTAR PUSTAKA}

Azwar, S. (2009). Sikap Manusia Teori dan Pengukurannya. Yogyakarta: Pustaka Pelajar.

Carin, A. A. (1997). Teaching Science Through Discovery Eight Edition. Columbus, Ohio: Merrill Publishing Co.

Carnevale, D. (2003). The Virtual Lab Experiment. [Online]. Tersedia: http://chronicle.com/weekly/v49/i21/ 21a03001.htm (20 September 2012).

Fitriani, I. (2012). Pembelajaran Evolusi Berbantuan Praktikum Virtual untuk Meningkatkan Kemampuan dan Disposisi Berpikir Kritis, Sikap Ilmiah, serta Penguasaan Konsep Evolusi pada Mahasiswa Calon Guru. Tesis Pascasarjana Program Studi Pendidikan IPA Konsentrasi Pendidikan Biologi UPI: tidak diterbitkan. 
Halaman : 013 - 019

Fraenkel, J.R. dan Wallen, N.E. (2007). How to Design and Evaluate Research in Education. New York: McGraw-Hill Companies.

Hill, J.L. dan Nelson, A. (2011). New Technology, New Pedagogy? Employing Video Podcast in Learning and Teaching about Exotic Ecosystems. Dalam Environmental Education Research [Online], Vol. 17 (3), 16 halaman. Tersedia: http://www.tandfonline.com/loi/ceer2 $\underline{0}$ (16 Februari 2012).

Iswari, S. (2008). Pembelajaran Biologi metode Inkuiri Terbimbing Menggunakan Lab Riil dan Lab Virtual Ditinjau dari Sikap Ilmiah dan Gaya Belajar Siswa. Tesis Pascasarjana UNS Solo: tidak diterbitkan.

Keller, H. E, dan Keller, E.E. (2005). Making Real Virtual Labs. The Science Education Review, 4 (1), 1-10.

McMaster. (2011). Can Virtual Labs Produce Real Scientifics?. [Online]. Tersedia: http://www.mcmaster.ca/inabis98/ran gachariedu/rangachari0320/two.html (14 Mei 2013).

Meltzer, D. E. (2002). The Relationship Between Mathematics Preparation and Conceptual Learning Gain in Physics: A Possible "Hidden Variable in Diagnostic Pretest Scores. American Journal Physics. 70 (12), 1259-1268.

Rustaman, N.Y., Dirdjosoemarto, S., Yudianto, S.A., Achmad, Y. Subekti, R., Rochintaniawati, D., Nurjani, M. (2003). Strategi Belajar Mengajar Biologi Common Text Book. Jurusan Pendidikan Biologi FPMIPA UPI.

Schafresman, S.D. (1991). Introduction to Critical Thinking. [Online]. Tersedia: http://www.freeinquiry.com/criticalthi nking.html (13 Oktober 2011).

Tapilouw, F. S. (2011). Variabel dan Hipotesis. Handout perkuliahan Metode Penelitian Pascasarjana, UPI Bandung. 